\title{
UJI TOKSISITAS EKSTRAK DAUN AFRIKA (Vernonia amygdalina) DENGAN METODE Brine Shrimp Lethality Test (BSLT)
}

\author{
Nur Hasanah, Billy Arnanda \\ Sekolah Tinggi Ilmu Kesehatan Kharisma Persada \\ Tangerang Selatan, 15417 \\ E-mail: Nurhasanahbik51@gmail.com
}

\begin{abstract}
ABSTRAK
Daun afrika (Vernonia amygdalina) merupakan salah satu tumbuhan obat yang tumbuh di Indonesia. Daun ini mengandung senyawa alkaloid, saponin, tanin, fenolik, flavonoid, triterpenoid, steroid dan glikosida. Tujuan penelitian ini adalah untuk mengetahui toksisitas ekstrak daun afrika (Vernonia amygdalina), mengetahui tampilan fisik ekstrak daun afrika (Vernonia amygdalina), dan mengetahui kandungan kimia daun afrika (Vernonia amygdalina). Metode yang digunakan dalam penelitian ini yaitu metode Brine Shrimp Lethality Test (BSLT). Penelitian ini menggunakan hewan uji larva Artemia salina Leach yang dibagi dalam 5 kelompok, tiap kelompok terdiri dari 10 ekor, dengan replikasi 2 kali tiap kelompok. Konsentrasi ektrak daun afrika (Vernonia amygdalina) yang digunakan yaitu 1 ppm, 10 ppm, 20 ppm, 100 ppm, dan 500 ppm dan dilakukan partisi ekstrak dengan pelarut etanol, n-Heksan, dan etil asetat. Pengamatan terhadap larva yang mati dilakukan 24 jam setelah pemberian ekstrak. Berdasarkan data, $\mathrm{LC}_{50}$ ekstrak daun afrika (Vernonia amygdalina) ditentukan dengan analisa probit. Hasil dari analisa probit menunjukkan $\mathrm{LC}_{50}$ fase etanol menunjukkan nilai $123 \mathrm{ppm}$, fase n-Heksan menunjukan nilai LC $_{50} 3548 \mathrm{ppm}$, dan fase etil asetat tidak memiliki nilai $\mathrm{LC}_{50}$. Hasil itu menunjukan bahwa hanya ekstrak fase etanol daun afrika (Vernonia amygdalina) yang mempunyai potensi toksik, hal ini ditunjukkan dengan harga $\mathrm{LC}_{50}>1000 \mathrm{ppm}$.
\end{abstract}

Kata Kunci: Toksisitas, ekstrak daun afrika (Vernonia amygdalina), Brine Shrimp Lethality Test (BSLT).

\begin{abstract}
Vernonia amygdalina is one kind of medical plant in Indonesia. The leaves contains alkaloids, saponins, tannin, phenolics, flavonoids, triterpenoids, steroid and glycosides bioactive compounds. The aims of the research is determine the lethal toxicity value of Vernonia amygdalina, determine physical appearance of Vernonia amygdalina, and determine bioactive compounds of Vernonia amygdalina. The method used in this research is Brine Shrimp Lethality Test (BSLT) method. This research use larva Artemia salina Leach that devided into 5 groups. Each group consist of 10 larva with two replications. Vernonia amygdalina concentration used are $1 \mathrm{ppm}, 10 \mathrm{ppm}, 20 \mathrm{ppm}, 100 \mathrm{ppm}$, and $500 \mathrm{ppm}$ and done extract partition with ethanol, n-Hexane, and ethyl acetate. Observations were made during 24 hours of Artemia salina Leach mortality. Based on the data, $L C_{50}$ Vernonia amygdalina determined by probity analysis. The result of probity analysis shows ethanol extract is $123 \mathrm{ppm}, L C_{50} n$-Hexane extract is $3548 \mathrm{ppm}$, and ethyl acetate extract has no $L C_{50}$. The result indicates only ethanol extract having toxic value. In this case indicates with $L C_{50}>1000$ ppm.
\end{abstract}

Keywords: Toxicity, Vernonia amygdalina, Brine Shrimp Lethality Test (BSLT). 


\section{LATAR BELAKANG}

Penggunaan herbal sebagai obatobatan tradisional telah diterima luas di negara-negara maju maupun berkembang sejak dahulu, bahkan dalam 20 tahun terakhir perhatian dunia terhadap obatobatan tradisional semakin meningkat, baik di negara yang sedang berkembang maupun negara-negara maju. World Health Organization (WHO) atau Badan Kesehatan Dunia menyebutkan bahwa hingga $65 \%$ dari penduduk negara maju menggunakan pengobatan tradisional dan obat-obat dari bahan alami (Departemen Kesehatan RI, 2000).

Semua spesies tanaman yang ada di dunia sebenarnya berguna untuk manusia. Namun hanya beberapa tanaman tertentu yang secara alami memiliki sifat obat. Kualitas tanaman obat ditentukan oleh struktur bahan kimia yang menyusunnya. Setiap spesies tanaman mengandung bahan kimia yang dapat mempengaruhi makhluk hidup lain (Savitri A, 2016).

Secara umum, tanaman mensintesis senyawa yang disebut metabolit primer, yakni protein, lemak, dan karbohidrat. Senyawa - senyawa tersebut sangat penting untuk keberlangsungan hidup dan reproduksi tanaman dan juga untuk hewan atau manusia yang mengkonsumsinya (Savitri A, 2016).

Tanaman obat selain mensintesis metabolit primer, juga mensintesis sejumlah komponen tumbuhan, yang disebut metabolit sekunder. Metabolit sekunder digunakan untuk pertahanan diri bagi tanaman diantaranya melindungi tanaman terhadap jamur, bakteri, hewan, bahkan tanaman lain. Metabolit sekunder memainkan peran penting dalam melawan penyakit dan predator bagi tanaman. Dengan kata lain, senyawa sekunder dalam keadaan murni bisa menjadi obat sekaligus racun bagi makhluk hidup lain yang mengkonsumsinya (Savitri, 2016).

Indonesia merupakan negara di benua Asia yang terkenal karena keanekaragamannya, baik keanekaragaman suku bangsa maupun keanekaragaman alamnya. Salah satu keanekaragaman alam yang dimiliki Indonesia adalah keanekaragaman hayati khususnya tumbuhan. Selain itu Indonesia juga memiliki keanekaragaman etnis yang memiliki berbagai macam pengetahuan tentang obat tradisional yang menggunakan bahan-bahan dari tumbuhan. Banyak dari jenis tumbuhan itu telah ribuan tahun digunakan oleh nenek moyang bangsa Indonesia dan dokter sebagai bahan obat atau jamu 
tradisional untuk berbagai macam penyakit dan memberikan hasil yang baik bagi pemeliharaan kesehatan serta pengobatan. Di bumi ini diperkirakan terdapat 40.000 spesies tumbuhan. Dari jumlah tersebut sekitar 30.000 spesies hidup di kepulauan Indonesia dan sekurang-kurangnya $\quad 9.600 \quad$ spesies diketahui berkhasiat obat, tetapi baru 300 spesies yang telah dimanfaatkan sebagai bahan baku obat tradisional dan industri obat tradisional (Departemen Kesehatan RI, 2000).

Indonesia memiliki keanekaragaman hayati yang sangat lengkap. Anugerah ini membuat Indonesia menjadi negara pengobatan herbal terbaik di dunia. Beragam jenis tanaman obat dapat tumbuh dengan subur di Indonesia. Tanaman obat menjadi bahan utama dalam pembuatan jamu dan obat-obatan herbal (Hariana A, 2013).

Salah satu tanaman obat yang terdapat di Indonesia adalah daun afrika (vernonia amygdalina), yang diketahui memiliki efektivitas yang sangat besar. Daun afrika mengandung flavonoid, glikosida, saponin, tannin, dan triterpenoid/steroid (Setiawan, 2012). Senyawa-senyawa tersebut merupakan kandungan paling utama dari daun afrika. Daun afrika berasal dari benua Afrika, khususnya Nigeria, Kamerun dan Zimbabwe. Daun afrika di Nigeria sering digunakan untuk bahan makanan dan obat tradisional yang dikombinasikan dengan tanaman lain untuk mengobati berbagai penyakit. Seiring berjalannya waktu daun afrika semakin banyak digunakan di berbagai negara salah satunya Indonesia (Ijeh, 2010).

Tulisan-tulisan ilmiah mengenai tanaman afrika masih sangat terbatas, terutama daunnya yang sangat bermanfaat untuk kesehatan. Hal ini patut disayangkan karena berlimpahnya jumlah daun afrika di Indonesia khususnya di daerah Batang, Jawa Tengah serta khasiat daun afrika yang sangat bermanfaat bagi masyarakat. Penelitian yang akan dilakukan meliputi uji toksisitas dari ekstrak daun afrika. Uji toksisitas ini akan dilakukan menggunakan metode Brine Shrimp Lethality Test (BSLT) pada larva udang tujuannya untuk mengetahui ada tidaknya kandungan toxic (racun) dalam daun afrika.

Berdasarkan penjelasan dan data penggunaan obat tradisional maka dapat diketahui masalah dalam penelitian ini adalah masih kurangnya pemanfaatan dan tulisan ilmiah tentang obat tradisional dari daun afrika. Oleh karena itu, peneliti bermaksud melakukan penelitian yang berjudul Uji Toksisitas Ekstrak Daun Afrika (Vernonia amygdalina) Dengan 


\section{METODE}

Instrumen penelitian yang digunakan adalah alat-alat laboratorium seperti gelas ukur merek phyrex, tabung reaksi merek phyrex, neraca analitik, pipet, batang pengaduk kaca, cawan, penjepit kayu, oven, water bath, kertas saring dan alat-alat tambahan lain seperti pisau, kain flannel, dan airator merek Nikita Star, arus $=3,5 \mathrm{~L} /$ menit. Bahan yang digunakan adalah daun afrika (Vernonia amygdalina), etanol, n-Heksan, etil asetat, larva Artemia salina Leach, dan air laut.

Sampel yang digunakan pada penelitian ini adalah daun afrika yang diambil dari Desa Sembojo, Kecamatan Tulis, Kabupaten Batang, Jawa Tengah. Daun afrika segar seberat $2 \mathrm{Kg}$ dipotong kecil-kecil kemudian dikeringkan dengan cara diletakkan di tempat terbuka dengan sirkulasi udara yang baik dan tidak terkena langsung sinar matahari. Karena pada pengeringan langsung terhadap sinar matahari akan merusak komponen aktif pada daun afrika. Selanjutnya simplisia daun afrika diekstraksi dengan metode maserasi, dengan cara merendam daun afrika dalam pelarut etanol $70 \%$ selama 24 jam, lalu disaring dengan kain flannel dan direndam kembali dalam etanol $70 \%$ sampai tersari atau terekstraksi sempurna yang ditandai dengan warna etanol menjadi bening kembali. Setelah itu, pelarut etanol yang masih tersisa diuapkan pada penangas air atau water bath sambil diaduk sehingga didapatkan ekstrak yang kental.

Penetasan larva Artemia salina Leach dilakukan selama 48 jam. Penetasan dilakukan dengan cara merendam telur tersebut dalam air laut secukupnya pada wadah. Sebelumnya wadah dipasang aerator, aerator ini berguna untuk menjaga kadar oksigen dalam wadah. Wadah yang telah terisi telur dan telah dipasangi aerator selanjutnya diletakkan di ruang yang cukup cahaya. Cahaya ini berfungsi untuk pertumbuhan larva Artemia salina Leach. Dalam waktu 48 jam telur akan berubah menjadi larva Artemia salina Leach (Mutiah D, 2010).

Setelah didapatkan larva Artemia salina Leach, dilakukan pembuatan larutan induk dengan ekstrak etanol daun afrika dengan konsentrasi 2000 ppm atau sebanyak 400 mg ekstrak dalam 200 ml air laut. Kemudian dilakukan pengenceran dengan air laut menjadi konsentrasi 1 
ppm, 10 ppm, 20 ppm, 100 ppm, 500 ppm.

Pembuatan partisi ekstrak nHeksan dilakukan dengan menimbang 2gram ekstrak etanol daun afrika dan disuspensikan dengan air sebanyak $20 \mathrm{ml}$, setelah larut kemudian dimasukkan dalam corong pisah dan ditambahkan dengan total n-Heksan sebanyak $65 \mathrm{ml}$, lalu diuapkan sampai mendapatkan ekstrak kental. Cara tersebut juga dilakukan pada pembuatan partisi ekstrak etil asetat.

10 ekor larva Artemia salina Leach dimasukkan kedalam tabung reaksi yang berisi $10 \mathrm{ml}$ konsentrasi $1 \mathrm{ppm}, 10$ $\mathrm{ml}$ konsentrasi 10 ppm, $10 \mathrm{ml}$ konsentrasi $20 \mathrm{ml}, 10 \mathrm{ml}$ konsentrasi 100 ppm, dan 10 ml konsentrasi 500 ppm. Selain itu, dibuat kontrol negatif yang berisi $10 \mathrm{ml}$ air laut tanpa penambahan ekstrak. Kriteria standar untuk menilai kematian larva udang adalah bila larva udang tidak menunjukkan pergerakan selama beberapa detik observasi. Setiap konsentrasi perlakuan dilakukan replikasi sebanyak 2 kali (duplo). Data yang dikumpulkan adalah data primer yang didapatkan dari jumlah larva udang yang mati 24 jam setelah perlakuan pada tiaptiap konsentrasi ekstrak daun afrika (Mutiah, 2010).

\section{HASIL}

Tabel 1. Hasil Partisi Ekstrak

\begin{tabular}{cccc}
\hline Parameter & Ekstrak & \multicolumn{2}{c}{ Partisi Ekstrak } \\
\cline { 3 - 4 } & Etanol & n-Heksan & Etil Asetat \\
\cline { 3 - 4 } Jumlah & 26,12 gram & 0,4 gram & 0,2 gram \\
\hline Rendemen & $6,35 \%$ & - & - \\
\hline Kadar Air & $11,25 \%$ & - & - \\
\hline $\begin{array}{c}\text { Kadar Abu } \\
\text { Kadar Abu } \\
\text { tak larut } \\
\text { asam }\end{array}$ & $14,69 \%$ & - & - \\
\hline $\begin{array}{c}\text { Organoleptis } \\
\text { M. Warna }\end{array}$ & Hijau Tua & Hijau Tua & \\
\hline aromatik & Aromatik & Hijau Tua \\
\hline b. Bau & Aromatik & & \\
\hline
\end{tabular}




\begin{tabular}{cccc} 
c. Bentuk & Pasta & Pasta & Pasta \\
\hline d. Rasa & Pahit & Pahit & Pahit \\
\hline
\end{tabular}

Berdasarkan Tabel 1, diketahui bahwa jumlah ekstrak etanol yang didapatkan adalah 26,12 gram, 0,4 gram didapatkan dari partisi ekstrak n-Heksan, dan 0,2 gram didapatkan dari partisi ekstrak etil asetat. Organoleptis yang didapatkan dari ketiga partisi ekstrak yaitu berwarna hijau tua, berbau aromatik, berbentuk pasta, dan memiliki rasa pahit

- Tabel 1. Hasil Uji Toksisitas Awal

\begin{tabular}{c|c}
\hline Crude Ekstrak & Nilai $\mathbf{L C}_{\mathbf{5 0}}(\mathbf{p p m})$ \\
\hline Fase Etanol & $123 \mathrm{ppm}$ \\
\hline Fase n-Heksan & $3548 \mathrm{ppm}$ \\
\hline Fase Etil Asetat & - \\
\hline
\end{tabular}

Berdasarkan tabel 2. Diketahui bahwa crude ekstrak yang memiliki nilai toksisitas paling tinggi yaitu pada fase etanol dengan nilai $\mathrm{LC}_{50}$ sebesar 123 ppm, selanjutnya fase $n$-Heksan memiliki nilai $\mathrm{LC}_{50} 3548$ ppm, dan fase etil asetat yang tidak memiliki nilai $\mathrm{LC}_{5}$.

Tabel 2. Hasil Uji Fitokimia

\begin{tabular}{c|c}
\hline Uji Fitokimia & Hasil \\
\hline Alkaloid & + \\
\hline Saponin & + \\
\hline Tanin & + \\
\hline Fenolik & + \\
\hline Flavonoid & + \\
\hline Triterpenoid & + \\
\hline Steroid & + \\
\hline Glikosida & + \\
\hline
\end{tabular}


Berdasarkan tabel 3. Diketahui bahwa ekstrak daun afrika memiliki kandungan alkaloid, saponin, tanin,

\section{DISKUSI}

Pengujian pada ekstrak daun afrika berfungsi untuk mengetahui toksik tidaknya daun afrika. Ekstrak etanol dengan berat 26,12 gram yang memiliki bentuk berupa pasta berwarna hijau tua pekat beraroma khas aromatik daun kemudian dilarutkan ke dalam pelarut organik polar hingga nonpolar secara berurutan. Penggunaan pelarut etanol karena etanol mempunyai polaritas yang tinggi sehingga dapat mengekstrak bahan lebih banyak dibandingkan jenis pelarut organik yang lain, etanol mempunyai titik didih yang rendah dan cenderung aman, serta etanol tidak berbahaya dan beracun (Gamse T, 2002). Partisi awal menggunakan pelarut $n$-heksan diperoleh fase $n$-heksan seberat $0,4 \mathrm{~g}$. Penggunaan pelarut $n$-heksan karena $n$-heksan bersifat nonpolar sehingga dapat menarik senyawa kimia nonpolar dari tumbuhan, dan $n$ heksan memiliki toksisitas relatif rendah (Gamse T, 2002). Selanjutnya menggunakan pelarut etil asetat diperoleh fase etil asetat seberat 0,2 g. Alasan menggunakan pelarut etil asetat karena etil asetat bersifat semipolar sehingga dapat menarik senyawa bersifat polar dan fenolik, flavonoid, triterpenoid, steroid, dan glikosida.

nonpolar, memiliki toksisitas rendah, dan mudah diuapkan (Gamse T, 2002).

Dari hasil penelitian menunjukan bahwa fraksi larut air yang menggunakan pelarut etanol diperoleh bahwa kematian larva $\left(\mathrm{LC}_{50}\right)$ berada pada konsentrasi 123 ppm. Hal ini menunjukkan bahwa senyawa toksik pada ekstrak daun afrika bersifat larut air atau polar. Senyawa polar dalam daun afrika diantaranya flavonoid, tanin, glikosida, dan fenolik. Senyawa-senyawa itu masuk dalam senyawa polar karena memiliki gugus hidroksil (Akbar B, 2010). Dengan konsentrasi 123 ppm tersebut daun afrika dapat digunakan sebagai antibakteri (Mayer, 1982).

Pada pengujian menggunakan pelarut etil asetat yang merupakan pelarut semipolar diperoleh bahwa tidak terjadi kematian larva $\left(\mathrm{LC}_{50}\right)$. Hal ini menunjukkan bahwa senyawa toksik daun afrika tidak bersifat semipolar.

Pada pengujian menggunakan pelarut $\mathrm{n}$-Heksan yang merupakan pelarut nonpolar menunjukkan bahwa kematian larva $\left(\mathrm{LC}_{50}\right)$ berada pada konsentrasi 3548 ppm. Hal ini menunjukkan bahwa senyawa yang tidak larut air yang 
terkandung dalam daun afrika tidak bersifat toksik karena senyawa dikatakan toksik apabila memiliki nilai $\mathrm{LC}_{50}$ kurang dari 1000 ppm (Mayer, 1982). Senyawa kimia daun afrika yang tak larut air diantaranya adalah steroid, steroid masuk ke dalam senyawa tak larut air karena memiliki golongan lipid.

Hasil uji toksisitas crude ekstrak daun afrika dengan metode BSLT menunjukkan bahwa ekstrak fase etanol (larut air) daun afrika memiliki nilai toksisitas paling tinggi dengan LC50 sebesar 123 ppm. Dengan tingginya nilai toksisitas fase etanol ada beberapa faktor yang mempengaruhinya diantaranya, kandungan senyawa polar pada daun afrika merupakan senyawa yang paling aktif dibandingkan dengan senyawa nonpolar dan semipolar pada daun. Menurut Mayer 1982, apabila fase atau ekstrak memiliki nilai LC $_{50} 123$ ppm atau LC50 > 30-200 ppm berpotensi sebagai antibakteri.

Hasil penelitian diperoleh bahwa ekstrak daun afrika mengandung alkaloid, saponin, tanin, fenolik, flavonoid, triterpenoid, steroid, glikosida. Aplikasi alkaloid yaitu sebagai analgesik, obat malaria, dan obat kanker (Akbar B, 2010).
Aplikasi saponin yaitu sebagai anti kanker, anti mikroba, meningkatkan sistem imunitas, dan dapat menurunkan kolesterol (Lenny S, 2006). Aplikasi tanin yaitu sebagai anti diare, anti bakteri, antioksidan, dan penawar racun (Akbar B, 2010). Aplikasi fenolik yaitu sebagai antioksidan, meningkatkan sistem kekebalan tubuh, dan meningkatkan sirkulasi darah (Wahyuni S, 2009). Aplikasi flavonoid yaitu sebagai anti diabetes, anti kanker, penyakit jantung, dan antioksidan (Wadodkar SG, 2008). Aplikasi triterpenoid yaitu sebagai antiseptik, antimikroba, efek ekspektoran, obat penyakit diabetes, dan mengatasi gangguan menstruasi (Lenny S, 2006). Aplikasi steroid yaitu sebagai obat jantung, stimulasi tumor prostat, dan obat gangguan hati (Murray K, 2009). Aplikasi glikosida yaitu sebagai analgesik, antibakteri, antitusif, dan anti kanker (Sumardjo D, 2006).

Hasil pada penelitian ini diperoleh bahwa kandungan fitokimia dalam ekstrak daun afrika yang menunjukan efek toksik adalah flavonoid, tanin, glikosida, dan fenolik. Dimana senyawa-senyawa tersebut merupakan senyawa yang larut air (larut dalam pelarut polar. 


\section{SIMPULAN}

Hasil Penelitian menunjukan bahwa nilai $\mathrm{LC}_{50}$ fraksi etanol daun afrika berada pada konsentrasi 123 ppm, fraksi etil asetat daun afrika tidak memiliki nilai $\mathrm{LC}_{50}$, dan nilai $\mathrm{LC}_{50}$ fraksi $\mathrm{n}-\mathrm{Heksan}$ daun afrika berada pada konsentrasi 3548 ppm. Organoleptis ekstrak daun afrika

\section{DAFTAR PUSTAKA}

Akbar B.2010. Tumbuhan Dengan Kandungan Senyawa Aktif Yang Berpotensi Sebagai Bahan Antifertilita.Jakarta: Adabia Press

Departemen Kesehatan Republik Indonesia, 2000 dalam Hanifatan H F.2012.Proses Pembuatan Jamu Sediaan Kapsul dan Analisis Pemanfaatan Metabolit Sekunder Daun Jati Belanda (Guazuma ulmifolia lamk) di CV. Herba Nirmala.Surakarta : Universitas Sebelas Maret Surakarta

Gamse T.2002.Liquid-Liquid Extraction and Solid Liquid Extraction. Institute of Thermal Process and Environmental Engineering.

Hariana A.2013.Tumbuhan Obat dan Khasiatnya.Jakarta : Penebar Swadaya Grup

Ibrahim N, Aprianti S, Arif M, Hardjoeno. 2006. Hasil Tes Laju Endap Darah Cara Manual dan Automatik. Indonesian Journal of Clinical Pathology and Medical Laboratory, Vol. 12, No. 2, Mar 2006: 45-48

Ijeh.2010.Current Perspectives on The Medical Potentials of Vernonia amygdalina Del. Journal of didapatkan hasil warna hijau tua, berbentuk pasta, berasa pahit, dan berbau aromatik. Hasil uji fitokimia diketahui bahwa flavonoid, tanin, glikosida, dan fenolik merupakan senyawa yang paling aktif yang terkandung dalam daun afrika.

Medicinal Plant Research 5(7):1051-1061

Lenny S.2006. Senyawa Triterpenoida dan Steroida. Medan: Universitas Sumatera Utara

Mayer, 1982 dalam Rizqillah N.2013.Uji Toksisitas Akut Ekstrak n-Heksan Daun Garcinia benthami Pierre Terhadap Larva Artemia Salina Leach Dengan Metode Brine Shrimp Lethality Test (BSLT).Jakarta : UIN Jakarta

Murray K.2009.Biokimia Harper Edisi 27.Jakarta:Buku Kedokteran EGC

Mutiah D.2010.Uji Toksisitas Akut Ekstrak Etanol Buah Anggur (Vitis Vinivera) Terhadap Larva Artemia Salina Leach Dengan Metode Brine Shrimp Lethality Test (BSLT).Semarang : Universitas Diponegoro

Savitri A.2016.Tanaman Ajaib! Basmi Penyakit dengan TOGA (Tanaman Obat Keluarga).Depok : Bibit Publisher

Silvani H, Sureskiarti E .2016. Hubungan peran aktif keluarga sebagai pengawas minum obat (PMO) Dengan angka kekambuhan TB paru di ruang seruni RSUD abdul wahab sjahranie Samarinda. Jurnal Ilmu 
Kesehatan.Vol.4 No. 2, Desember 2016

Sumardjo

D.2006.Pengantar

Kimia.Jakarta : Kedokteran EGC
Wahyuni S.2009.Tumbuhan Obat Hias Berpotensi.Jakarta:Elex Media Komputindo 